\title{
DESIGNING AND PREPARING THE STRATEGIC PLAN OF WOMEN'S CHAMPIONSHIP SPORTS OF GUILAN PROVINCE
}

\author{
* Shahram Shafiee \\ **Fatemeh Saeedi \\ **Fatemeh Katebi Jahromi \\ *Assistant Professor University of Guilan \\ ** MA Student of Sports Management in University of Guilan
}

\begin{abstract}
The aim of the present study was to design and prepare the strategic plan of women's championship sports of Guilan Province. The research method was descriptive and of case-study types. Also, the population of the study consisted of the Sports and Youth Office experts, coaches and referees, and the former and current players and champions of Guilan. Due to the limited population size, the sample involved 40 subjects who were selected using the census sampling method. . In order to gather the data, library resources, a review of related literature, interviews and questionnaires were used. After preparing the structured questionnaire as the framework and guideline of the research, its content validity was checked by the experts and scholars of the field and also its reliability was confirmed using Cronbach's alpha test with the coefficient of 0.85. Furthermore, the Friedman test was used for ranking the indexes, while IFE and EFE matrixes were used for determining the position of the women's championship sports.

The results showed that high potential talents (Mean Rank=5.5) in strengths, sport facilities and places (Mean Rank=5.49) in weaknesses, the number of educated women (Mean Rank=3.4) in opportunities part, and quitting sports due to economic and livelihood problems (Mean Rank=6.34) in threats had the highest ranks. In general, using EFE and IFE matrixes, the position of women's championship sports of Guilan Province was determined in WT area. According to the results, in order to get out of this area, one should use the defensive strategies.
\end{abstract}

Key words: Championship, Guilan Province, Sport Women, SWOT analysis, Strategic Plan

\section{INTRODUCTION}

One of the most significant characteristics of developed countries is acknowledging the management knowledge as one of the main necessities of economic and social progress and development. The events in the last several decades, and the new needs arising in these years are so special that one cannot simply confront these events and needs, only by relying on the common and inflexible plans. Therefore, in the last three decades, the executive managers and the experts of the field, have focused on management and strategic planning (Ansoff, 1994). Olsen and Eadie (1982) have defined strategic planning as a disciplined effort to make essential decisions and actions that determines what an organization is and what it does. David (1998) and Fry and stoner (1995) define strategic planning as a powerful managerial instrument that is designed for contributing small organizations so that they could adapt to the predicted environmental changes, competitively.

The first value and priority of strategic planning is to help the organization perform successfully in a dynamic and complicate environment. Strategic planning is used as an instrument for making and guiding organizational changes (Hunger and Wheelen, 2003). It can be a way to recognize the current status while moving toward the desired future status, as well as an indicator of development process and programs implementation toward the goals (David, 1998). Moreover, today the organizations have to monitor the national and foreign events constantly so that they would be able to adapt to the changes, in the right time, according to the situation (Hunger and Wheelen, 2003).Studies show that the organizations that use 
strategic planning have better performance than the others. Reaching a proper type of relation among the environment of an organization and its strategies, structure and processes, maintains positive effects on the performance of that organization. Strategic planning enhances the capacity of the organization in resolving the problems and challenges of the organization (Pearce and Robinson, 1997). One of the phenomena that attracts global attention is sports industry. Sport has become an industry that profoundly influences the economic, social and even political indexes of the countries. Any country has to consider the main effective variables of sports, in order to have more authority on the significant resources and profits, in such a way that the massive profits of championship sports can encourage the policy-makers to develop the industry so that they can gain more profits for themselves (Hill and Jones, 1992).

Sport as one of the major social phenomena in the world has a very important role in humans' lives, and in this field, the championship sports have particular significance and position (Mester et al., 2008). Championship sports development is the stepping stone to successful performance in world and Olympic competitions. The presence of women as an important section of the society in the championship sports is an undeniable necessity. Championship sports are the field for women's self-determination and development and also an arena for changing the misogynistic stereotypes.

Recognition of a woman as the sports hero and model, consolidates the women's identity position, while it can give an opportunity to defend women's values and capacities, regardless of sexist and oppressive ideas. Rasekh e al. (2012) in a study under the title of "Designing the Strategic Plan for Women's Championship Sports in Iran”, showed that Iranian women's championship sport could use defensive strategies. Khabiri and memari (2011) in a research titled "SWOT Analysis of Taekwondo in Iran", identified the considerable increase in the number of women's teams participating in national competitions in the recent years as the strengths of taekwondo in Iran. Monazzami et al. (2011) in a study showed that "financial and facilities- related", "human and specialized", "structural and managerial", and "cultural and social" factors are influential in case of the women's sports development in Islamic Republic of Iran. Gould et al. (1999) in a study under the title of "Investigating the Effective Strategy on Female Athletes' Performance", revealed that the coaches are one of the most important factors underlying the success of sportswomen. Pitts and Pedersen (2005) in a study called "Investigating the body of knowledge in sport management: A content analysis of the Sport Marketing Quarterly" concluded that $81.2 \%$ of the articles were about men's sports, $14.1 \%$ dealt with the sports of both genders and $4.7 \%$ had no gender-oriented focus, while there was no article on the subject of women's sports. Such issue will not be resolved if there is not any encouragement for changing such imbalance in case of the article numbers related to men's and women's sports; since the study opportunities for women's sports are plenty. Dixon et al. (2008) in a study titled "The Parents' Impact on Women's Participation in Sport Activities", came to this conclusion that most of the women participating in the sport activities stated that one or both of their parents had actively participated in their school days in sports competitions and in fact they have been the model for the children. Guilan Province as one of the most talented provinces of Iran in sports and particularly in championship sports lack any comprehensive and long-term plan for women's championship sports development. In the present study, the aim is to design a strategic plan for women's championship sport of the province and identifying strengths, weaknesses, opportunities and threats of women while analyzing the external and internal environments. Hence, the main research question here is: What is the women's sports strategic plan in Guilan Province?

\section{METHODOLOGY}

The methodology of the present study is descriptive and a case-study, while in case of aim, the research is of applied type. The population of the present study consist of the experts of the Sports and Youth Office, coaches and referees, former athletes and the champion women of Guilan. Due to the small size of the study population, 40 subjects were selected as the sample using census sampling method. In order to gather the data, library resources, a review of related literature, interviews and questionnaires were used. Thus, after studying the current status and interviewing the experts of women's championship sports in the province, a draft of the strengths, weaknesses, opportunities and threats of the women's championship sports of Guilan was prepared. Then, the questionnaire of the research was designed by the experts of sports management after analysis and close review, in two parts. The first part includes the personal information of the subjects and the second part of the questionnaire concerns the investigation of 
strengths, weaknesses, opportunities and threats of women's championship sports of Guilan, prepared in four sections: 1- Strengths (7 questions), 2- Weaknesses (8 questions), 3- Opportunities (4 questions), 4Threats (9 questions) in the 5-point Likert scale. In order to determine the validity of the questionnaire, the opinions of scholars and experts were considered in the designing of the questionnaire, and some modifications were applied. Also, the reliability of the questionnaire was calculated by Cronbach's alpha test as $\alpha=0 / 858$. These questionnaires were distributed among the population of the study, and after collecting the done questionnaires, the strengths, weaknesses, opportunities and threats of championship

\section{DATA ANALYSIS METHODS}

The significant methods of strategy designing can be defined in a three-step decision-making framework. The presented methods in such framework are suitable for various organizations and they can help the strategists identify, assess and choose the best strategies. The first step is strategy planning, which involves a matrix of evaluating the internal factors and a matrix of evaluating the external factors. The matrix of evaluating the internal factors is a result of the strategic studying of internal factors of the organization, which determines the essential strengths and weaknesses of the organization. In the matrix of evaluating the external factors, the economic, social, cultural, ecological, environmental, political, governmental and other external factors of the organization are evaluated and this matrix determines the essential opportunities and threats of the organization.

In the second step which is called comparison step, the various possible strategies are considered and hence, a sort of balance is made among the internal and external factors of the organization. The methods and instruments that are used in the second step are:

1. The matrix of strengths, weaknesses, opportunities and threats: this matrix is one of the important instruments by which the managers compare the data and they also can present four types of strategies (Such as SO, WO, ST, and WT) through this matrix.

2. Internal and External Factors Matrix: in this part, it is determined that the organization should use what type of strategies (Growth, Product, Maintenance and Defensive).

\section{RESULTS AND DISCUSSION}

Tables 1 to 6 show the overall results in case of the strengths, weaknesses, opportunities and threats of women's championship sports in Guilan Province. Each of the factors presented in the tables which involve SWOT, based on the analysis of seven strengths, eight weaknesses, four opportunities and nine threats, are shown in order of their ranks, according to Freedman test results.

In Table 1, the Chi square statistic and the related contingency value are presented for the strengths and weaknesses of women's championship sports of Guilan. The numerical value of the contingency related to Chi-squared test equals to 0.001 which is smaller than 0.05 . Thus, the null hypothesis is not supported in the significance level of 95\%. Therefore, we can say that there is a significant difference among the indexes ranks related to the strengths and the weaknesses in the field of women's championship sports.

Table 1. Friedman significance of the strengths and weaknesses of women's championship sports of Guilan Province

\begin{tabular}{ccc}
\hline Statistical indicators & Strengths & weaknesses \\
\hline Number(N) & 40 & 40 \\
\hline Chi-Square & 77.40 & 26.11 \\
\hline Df & 6 & 7 \\
\hline Asymp. Sig & 0.001 & 0.001
\end{tabular}

In Table 2 and 3, the mean ranks of strengths and weaknesses of women's championship sports of Guilan are presented. After the ranking was done, it was determined that the highest rank in case of strengths is related to the item of enhancing the potential talents of women's sports in the province, both in team and individual teams, and in case of weaknesses, the best rank belonged to the sports facilities and equipment, considering the importance of women's usage of covered spaces. 
Journal of Global Strategic Management | V. 11 | N. 2 | 2017-December | isma.info | 005-086 | DOI: 10.20460/JGSM.2018.253

Table 2. The strength of women's championship sports of Guilan Province (Friedman test)

\begin{tabular}{clc}
\hline Priority & \multicolumn{1}{c}{ Factors } & Mean Rank \\
\hline 1 & $\begin{array}{l}\text { The high level of potential talents in women's sports of Guilan, both in team and } \\
\text { individual sports }\end{array}$ & 5.50 \\
\hline 2 & $\begin{array}{l}\text { The ambitiousness and high motivation of champion women of the province for } \\
\text { gaining national and international titles }\end{array}$ & 4.86 \\
\hline 3 & $\begin{array}{l}\text { Special and technical capacities of the high-level coaches of the province in order to } \\
\text { work in championship sports }\end{array}$ & 4.48 \\
\hline 4 & The ascending trend of champion women in gaining the national and Asian medals & 3.01 \\
\hline 5 & The presence of various women sport teams in national premier leagues & 3.61 \\
\hline 6 & $\begin{array}{l}\text { Increasing the level of knowledge in order to improve the public thought about the } \\
\text { women's championship sport }\end{array}$ & 2.30 \\
\hline 7 & The provincial officials' support of women's championship sports development & 2.24
\end{tabular}

Table 3. The weakness of women's championship sports of Guilan Province (Friedman test)

\begin{tabular}{clc}
\hline Priority & \multicolumn{1}{c}{ Factors } & Mean Rank \\
\hline 1 & $\begin{array}{l}\text { Sport facilities and spaces considering the importance of women's usage of covered } \\
\text { places }\end{array}$ & 5.49 \\
\hline 2 & $\begin{array}{l}\text { The System of scouting, recruiting and developing of the sport talents in women's } \\
\text { championship sports of the province }\end{array}$ & 4.86 \\
\hline 3 & Short-term and long-term planning in women's championship sports & 4.81 \\
\hline 4 & Radio and TV programs in Guilan for making the champion women public & 4.60 \\
\hline 5 & $\begin{array}{l}\text { Considering the research and development system in women's championship sports of } \\
\text { the province and the rate of using scientific advices }\end{array}$ & 4.43 \\
\hline 6 & $\begin{array}{l}\text { The level of authority and share of Guilan's women in decision-making and planning } \\
\text { of championship sports }\end{array}$ & 4.21 \\
\hline 7 & Not allocating the enough budget to women's championship sports of Guilan & 3.55 \\
\hline 8 & The presence of the spectators &
\end{tabular}

In Table 4, the Chi square statistic and the related contingency value are presented for the opportunities and threats of women's championship sports of Guilan. . The numerical value of the contingency related to Chi-squared test equals to 0.001 which is smaller than 0.05 . Thus, the null hypothesis is not supported in the significance level of $95 \%$. Hence, we can say that the weaknesses and the strengths of the championship sports of Guilan are not at the same level.

Table 4. Friedman significance of the opportunities and threats of women's championship sports of Guilan Province

\begin{tabular}{ccc}
\hline Statistical indicators & opportunities & threats \\
\hline Number(N) & 40 & 40 \\
\hline Chi-Square & 41.17 & 39.34 \\
\hline Df & 3 & 8 \\
\hline Asymp. Sig & 0.001 & 0.001 \\
\hline
\end{tabular}

In Table 5 and 6, the mean ranks of opportunities and threats are presented. In the part of opportunities, the highest rank is related to the number of women educated in Physical Education field, and in case of the threats the best rank belongs to quitting sports due to economic and livelihood problems. 
Journal of Global Strategic Management | V. 11 | N. 2 | 2017-December | isma.info | 063-076 | DOI: 10.20460/JGSM.2018.253

Table 5.The opportunities of women's championship sports of Guilan Province (Friedman test)

\begin{tabular}{clc}
\hline Prioriy & \multicolumn{1}{c}{ Factors } & Mean Rank \\
\hline 1 & The large number of women educated in Physical Education field & 3.40 \\
\hline 2 & $\begin{array}{l}\text { The tendency of women to take part in championship sport activities and the presence } \\
\text { in national and foreign fields }\end{array}$ & 2.53 \\
\hline 3 & $\begin{array}{l}\text { The geographical location of the province and using the natural spaces like open } \\
\text { plains, mountains, etc. }\end{array}$ & 2.16 \\
\hline 4 & Women's participation in water sports & 1.91 \\
\hline
\end{tabular}

Table 6. The threats of women's championship sports of Guilan Province (Friedman test)

\begin{tabular}{clc}
\hline Prioriy & \multicolumn{1}{c}{ Factors } & Mean Rank \\
\hline 1 & Quitting sports due to economic and livelihood problems & 6.43 \\
\hline 2 & $\begin{array}{l}\text { The existence of problems caused by marketing and sponsorship of private sector in } \\
\text { women's championship sports }\end{array}$ & 5.69 \\
\hline 3 & $\begin{array}{l}\text { The presence of inefficient and non-athletic managers in different managerial levels of } \\
\text { women's championship sports }\end{array}$ & 5.40 \\
\hline 4 & The cultural limitations in society in case of women's sports & 4.99 \\
\hline 5 & Weak media coverage due to some limitations such as women's hijab & 4.98 \\
\hline 6 & The lack of officials' support of water sports development in women's case & 4.86 \\
\hline 7 & The costs of participating in championship sports competitions & 4.74 \\
\hline 8 & Unclear policies and decisions in women's championship sports of Guilan & 4.45 \\
\hline
\end{tabular}

The Matrix of Internal and External Factors of Women's Championship Sports of Guilan In this part, it should be cleared that the women's championship sport of Guilan uses what strategies (Growth, Product, Maintenance or Defensive).

In the matrix of evaluating the internal and external factors, regardless of the number of factors which cause the strength or weakness or are considered as the opportunities or threats of Guilan's women's championship sports, the total sum of the final scores never goes beyond four, and also never is lower than 1 . The weighted mean score is 2.5 and if this point reaches up to 4, it means that the organization reacts extraordinarily to the factors which are the causes of threat and opportunity and if the weighted point (weight * ranking) of the internal and external factors reaches lower than the average, it indicates that the organization has not utilized the strengthening factors in strategies planning, nor it could evade the factors which bring about threats. Also, the matrix of evaluating the internal and external factors of women's championship sports is the result of strategic investigation of internal and external factors of the organization. The internal and external factors were analyzed in case of two dimensions of importance and rank (current status). According to the importance and potential effectiveness value of each factor, a point from 1 to 10 was given.The total points of various factors were summed and by dividing the point of each factor by the total sum points, its importance coefficient was calculated (The sum of importance coefficient of all the internal or external factors equal to 1 ).

Also, based on the current status, the rank of each factor was determined and each of them were given some point from 1, as the full weakness to 4 as the full strength. By multiplying the rank of each factor by the importance coefficient, the final score of each factor was determined and according to the final score, that group of internal factors which gained the highest point were classified as the strengths, and those factors who had the least points were regarded as the weaknesses. Also, based on the final points of external factors, the opportunities and threats were determined. These matrixes present and assess the main strengths, weaknesses, opportunities, and threats whose threats are shown in Table 7 and 8. Finally, women's championship sports of Guilan have not used the best of the opportunities and have done poorly in controlling the threats. 
In sum, the results of internal and external matrixes in Figure 1, shows that the women's championship sports are at WT situation, in case of strategic situation. In other words, one can say that due to the dominance of weaknesses over the strengths and considering the incapability of women's championship sports of Guilan in using the opportunities and evading the possible threats, it is better to have defensive strategy so that the women's championship sports status in Guilan does not get worse than the current status.

Table 7: Internal factors evaluation matrix of women’s championship sports of Guilan Province

\begin{tabular}{|c|c|c|c|c|c|}
\hline $\begin{array}{l}\text { Internal } \\
\text { factors }\end{array}$ & row & Factors & $\begin{array}{l}\text { Importan } \\
\text { ce Index } \\
\text { (Weight) }\end{array}$ & Score & $\begin{array}{l}\text { The final } \\
\text { score } \\
\text { (Weight } \times \\
\text { score) }\end{array}$ \\
\hline \multirow{7}{*}{ 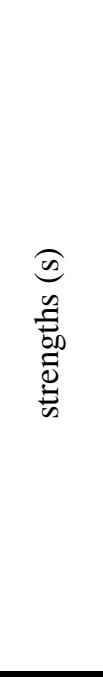 } & $\mathrm{S} 1$ & $\begin{array}{l}\text { The ambitiousness and high motivation of } \\
\text { champion women of the province for gaining } \\
\text { national and international titles }\end{array}$ & 0.070 & 4 & 0.28 \\
\hline & S2 & $\begin{array}{l}\text { The ascending trend of champion women in } \\
\text { gaining the national and Asian medals }\end{array}$ & $0 / 069$ & 3 & 0.28 \\
\hline & S3 & $\begin{array}{l}\text { Increasing the level of knowledge in order to } \\
\text { improve the public thought about the women's } \\
\text { championship sport }\end{array}$ & 0.064 & 3 & 0.19 \\
\hline & S4 & $\begin{array}{l}\text { The provincial officials' support of women's } \\
\text { championship sports development }\end{array}$ & 0.065 & 3 & 0.20 \\
\hline & S5 & $\begin{array}{l}\text { The high level of potential talents in women's } \\
\text { sports of Guilan, both in team and individual } \\
\text { sports }\end{array}$ & 0.070 & 4 & 0.28 \\
\hline & S6 & $\begin{array}{l}\text { Special and technical capacities of the high-level } \\
\text { coaches of the province in order to work in } \\
\text { championship sports }\end{array}$ & 0.069 & 4 & 0.28 \\
\hline & S7 & $\begin{array}{l}\text { The presence of various women sport teams in } \\
\text { national premier leagues }\end{array}$ & 0.066 & 4 & 0.26 \\
\hline \multirow{9}{*}{ 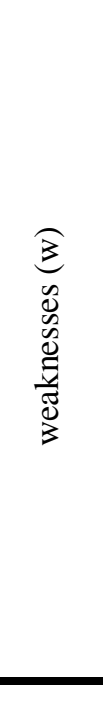 } & W1 & $\begin{array}{l}\text { Not allocating the enough budget to women's } \\
\text { championship sports of Guilan }\end{array}$ & 0.065 & 1 & 0.065 \\
\hline & W2 & $\begin{array}{l}\text { Sport facilities and spaces considering the } \\
\text { importance of women's usage of covered places }\end{array}$ & 0.066 & 1 & 0.066 \\
\hline & W3 & $\begin{array}{l}\text { Short-term and long-term planning in women's } \\
\text { championship sports }\end{array}$ & 0.066 & 1 & 0.066 \\
\hline & W4 & $\begin{array}{l}\text { The System of scouting, recruiting and } \\
\text { developing of the sport talents in women's } \\
\text { championship sports of the province }\end{array}$ & 0.066 & 1 & 0.066 \\
\hline & W5 & $\begin{array}{l}\text { The level of authority and share of Guilan's } \\
\text { women in decision-making and planning of } \\
\text { championship sports }\end{array}$ & 0.063 & 1 & 0.063 \\
\hline & W6 & $\begin{array}{l}\text { Considering the research and development system } \\
\text { in women's championship sports of the province } \\
\text { and the rate of using scientific advices }\end{array}$ & 0.066 & 1 & 0.066 \\
\hline & W7 & $\begin{array}{l}\text { Radio and TV programs in Guilan for making the } \\
\text { champion women public }\end{array}$ & 0.067 & 1 & 0.067 \\
\hline & W8 & The presence of the spectators & 0.067 & 1 & 0.067 \\
\hline & & Sum & 1 & & 2.296 \\
\hline
\end{tabular}


Table 8: External factors evaluation matrix of women’s championship sports of Guilan Province

\begin{tabular}{|c|c|c|c|c|c|}
\hline $\begin{array}{l}\text { External } \\
\text { factors }\end{array}$ & row & Factors & $\begin{array}{l}\text { Importan } \\
\text { ce Index } \\
\text { (Weight) }\end{array}$ & Score & $\begin{array}{c}\text { The final } \\
\text { score } \\
\text { (Weight } \times \\
\text { score) }\end{array}$ \\
\hline \multirow{4}{*}{ 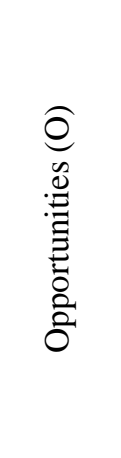 } & O1 & $\begin{array}{l}\text { The geographical location of the } \\
\text { province and using the natural spaces } \\
\text { like open plains, mountains, etc. }\end{array}$ & 0.088 & 4 & 0.35 \\
\hline & $\mathrm{O} 2$ & $\begin{array}{l}\text { Women's participation in water } \\
\text { sports }\end{array}$ & 0.088 & 3 & 0.26 \\
\hline & $\mathrm{O} 3$ & $\begin{array}{l}\text { The tendency of women to take part } \\
\text { in championship sport activities and } \\
\text { the presence in national and foreign } \\
\text { fields }\end{array}$ & 0.088 & 4 & 0.35 \\
\hline & $\mathrm{O} 4$ & $\begin{array}{l}\text { The large number of women } \\
\text { educated in Physical Education field }\end{array}$ & 0.091 & 4 & 0.36 \\
\hline \multirow{10}{*}{ 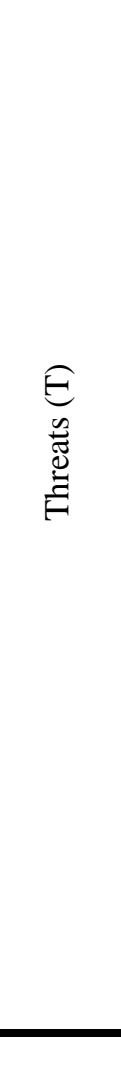 } & $\mathrm{T} 1$ & $\begin{array}{l}\text { The cultural limitations in society in } \\
\text { case of women's sports }\end{array}$ & & 2 & \\
\hline & $\mathrm{T} 2$ & $\begin{array}{l}\text { The costs of participating in } \\
\text { championship sports competitions }\end{array}$ & 0.077 & 1 & 0.077 \\
\hline & $\mathrm{T} 3$ & $\begin{array}{l}\text { Quitting sports due to economic and } \\
\text { livelihood problems }\end{array}$ & 0.062 & 2 & 0.12 \\
\hline & $\mathrm{T} 4$ & $\begin{array}{l}\text { Weak media coverage due to some } \\
\text { limitations such as women's hijab }\end{array}$ & 0.067 & 2 & 0.13 \\
\hline & $\mathrm{T} 5$ & $\begin{array}{l}\text { The presence of inefficient and non- } \\
\text { athletic managers in different } \\
\text { managerial levels of women's } \\
\text { championship sports }\end{array}$ & 0.066 & 2 & 0.13 \\
\hline & T6 & $\begin{array}{l}\text { The existence of problems caused by } \\
\text { marketing and sponsorship of private } \\
\text { sector in women's championship } \\
\text { sports }\end{array}$ & 0.069 & 2 & 0.14 \\
\hline & $\mathrm{T} 7$ & $\begin{array}{l}\text { Sports finances and budgets in } \\
\text { women's sector }\end{array}$ & 0.086 & 1 & 0.086 \\
\hline & $\mathrm{T} 8$ & $\begin{array}{l}\text { The lack of officials' support of } \\
\text { water sports development in } \\
\text { women's case }\end{array}$ & 0.077 & 2 & 0.15 \\
\hline & T9 & $\begin{array}{l}\text { Unclear policies and decisions in } \\
\text { women's championship sports of } \\
\text { Guilan }\end{array}$ & 0.075 & 1 & 0.075 \\
\hline & & Sum & 1 & & $2 / 358$ \\
\hline
\end{tabular}




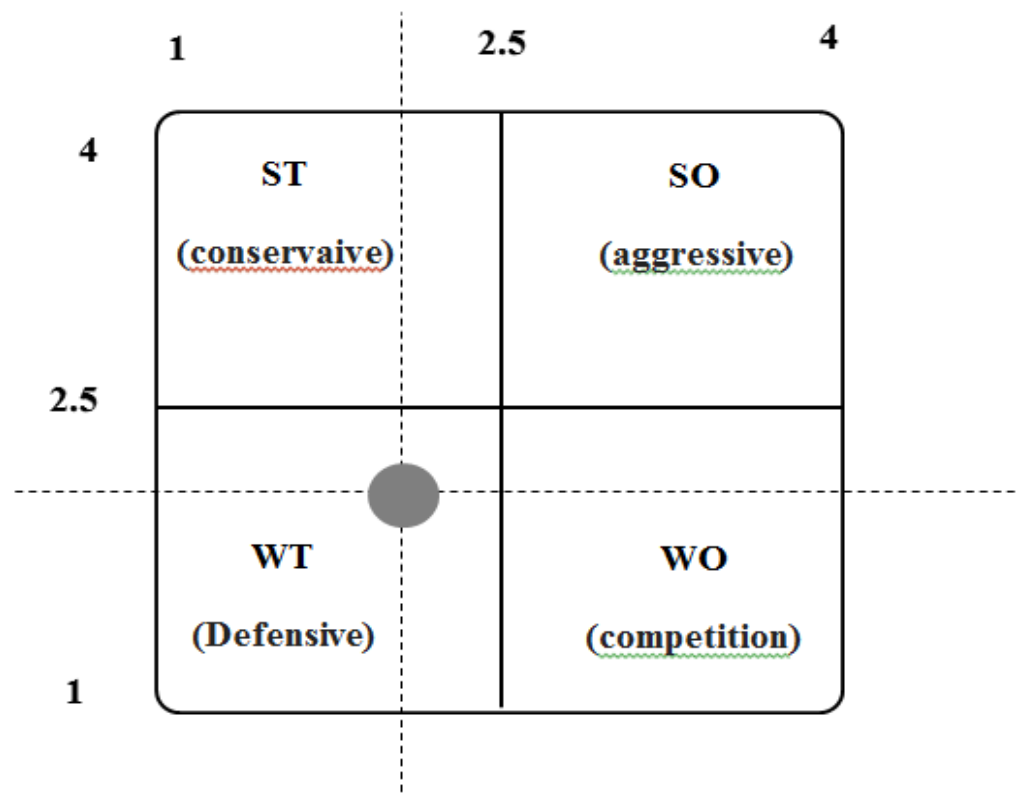

Figure 1. SWOT graph indicating Strategic Position and Action Evaluation Matrix (SPACEM) of women's championship sports of Guilan Province

In table 9, In the SWOT analysis, a total of 9 strategies were provided. one SO strategies, three ST strategies, two WO strategies and three WT strategies were developed for the women's championship sports of Guilan Province. 


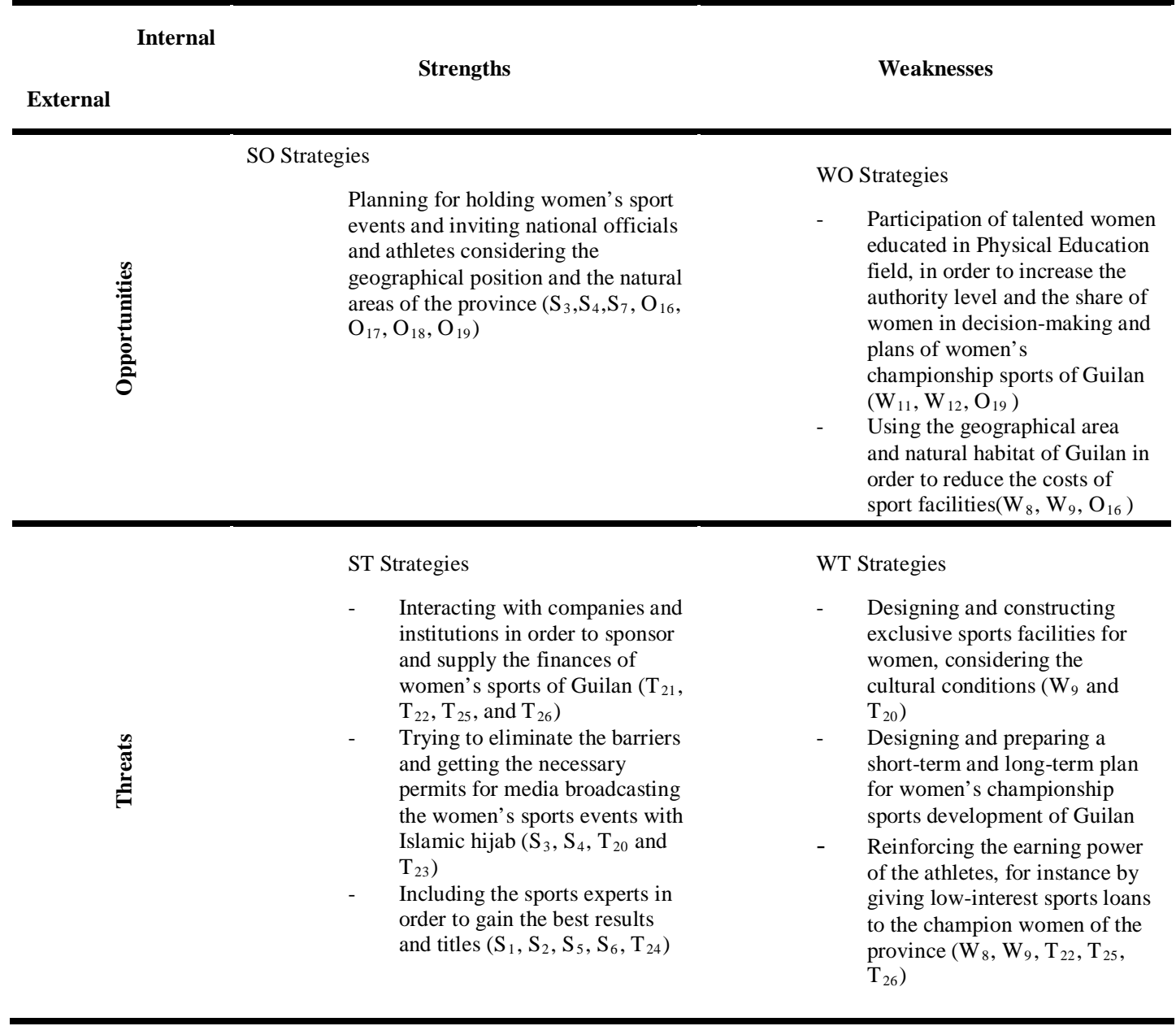

Designed strategies in order to develop the women’s championship sports of Guilan.

\section{SO Strategies}

- Planning for holding women's sport events and inviting national officials and athletes considering the geographical position and the natural areas of the province $\left(\mathrm{S}_{3}, \mathrm{~S}_{4}, \mathrm{~S}_{7}, \mathrm{O}_{16}, \mathrm{O}_{17}, \mathrm{O}_{18}, \mathrm{O}_{19}\right)$.

\section{WO Strategies}

- Participation of talented women educated in Physical Education field, in order to increase the authority level and the share of women in decision-making and plans of women's championship sports of Guilan.

- Using the geographical area and natural habitat of Guilan in order to reduce the costs of sports facilities $\left(\mathrm{W}_{8}, \mathrm{~W}_{9}, \mathrm{O}_{16}\right)$.

\section{ST Strategies}

- Interacting with companies and institutions in order to sponsor and supply the finances of women's sports of Guilan $\left(\mathrm{T}_{21}, \mathrm{~T}_{22}, \mathrm{~T}_{25}\right.$, and $\left.\mathrm{T}_{26}\right)$.

- Trying to eliminate the barriers and getting the necessary permits for media broadcasting the women's sports events with Islamic hijab $\left(\mathrm{S}_{3}, \mathrm{~S}_{4}, \mathrm{~T}_{20}\right.$ and $\left.\mathrm{T}_{23}\right)$.

- Including the sports experts in order to gain the best results and titles $\left(\mathrm{S}_{1}, \mathrm{~S}_{2}, \mathrm{~S}_{5}, \mathrm{~S}_{6}, \mathrm{~T}_{24}\right)$. 
WT Strategies

- Designing and constructing exclusive sports facilities for women, considering the cultural conditions $\left(\mathrm{W}_{9}\right.$ and $\left.\mathrm{T}_{20}\right)$.

- Designing and preparing a short-term and long-term plan for women's championship sports development of Guilan.

- Reinforcing the earning power of the athletes, for instance by giving low-interest sports loans to the champion women of the province $\left(\mathrm{W}_{8}, \mathrm{~W}_{9}, \mathrm{~T}_{22}, \mathrm{~T}_{25}, \mathrm{~T}_{26}\right)$.

\section{CONCLUSIONS}

The review of the related literature showed that there are a lot of models for strategic planning that different organization use, based on their status. In general, despite the difference in numbers and the order of steps of the models, all of them nearly have the same structure. Although the position of women's championship sports of Guilan is in WT area, one should use the following defensive strategies.

- Designing and Constructing Exclusive Sports Facilities for Women, Considering the Cultural Conditions.

The limited range of space, the high density of the population and the disproportionate movement spaces compared to the population growth, are the limiting factors of proper physical activities. Cultural norms which exist in every society can be effective on most of life aspects. Generally, in Current Situation of Iran Society, although has been lots of developments in women sports but still they face many cultural restrictions in Sports and Physical activities. Motmaeni et al, (2014) reported that the lack of attention officials to women's sports, male-dominated culture and lack of investment in the development of women's sports places are the most important obstacles. Also, Ghahremani et al (2013) Confirmed that Cultural Obstacles are one obstacle Facing Female teachers of Marand City to Participate in sports activities.

These restrictions are obvious a country with such a culture, we can't expect that women participate in sport activities in public places, freely, because it is not accepted by men, as a good behavior by many of men and men in many public places like sport places has caused harassment of women, so the women should reconsider about their participation in sport activities according to this situation and consider these restriction in their sport programs. hence, as having the proper sports space is one of the most essential factors of quality enhancement of sports performance, we can clearly see that the lack of standard sports facilities and spaces has been the cause of sportswomen's slow progress.

- Designing And Preparing a Short-Term and Long-Term Plan for Women’s Championship Sports Development of Guilan.

In many countries, the government's plans are to optimize the women's free time in order to make them have physical and sports activities. Sport is an important instrument in the hand of the governments and states in order to guide the people toward the planned goals, as it is also the most widespread instrument for training all the people in the today's societies in industrial and developed countries. Thus, it is necessary that the states and the officials in charge execute the proper economic, social and cultural policies, create and deliver the facilities and services, provide the proper cultural and sports spaces and use incentive ways in order to prevent from wasting the free times and help to make them more efficient, so that the society's cultural and scientific aspects are enriched more. The sociocultural evolutions in Iran in recent years, make is it inevitable that in order to reach the determined goals, while making proper plans in case of passing the laws and policies, more attention is paid to the sports and the people's free time, especially girls and women.

- $\quad$ Reinforcing the Earning Power of the Athletes, For Instance by Giving Low-Interest Sports Loans to the Champion Women of the Province.

The economic problems and discrimination in allocating the credits to women's sports, are the issues of women's sports. This can be also seen in Maslow hierarchy of needs. In this hierarchy, the first levels of needs are physiologic ones. It can be simply observed that in absence of economic power, even securing 
food, clothes and home which are among the first human needs, may be in trouble. So pursuing other needs like human interests would be even more hard (Jahedi and Torkfar, 2015). Proper financial planning helps the sports officials to lighten the heavy financial burden upon the shoulders of athletes and their families. Meenaghan (2001) has regarded attracting the companies and organization for sponsorship, as of the ways of supplying the enough budget for sports activities, especially the championship activities. Gomez-Lopez (2010) have mentioned the reasons of not participating in sports activities, held in 1991 at the students' level in Almeria University of Spain, as the existence of some barriers such as time and lacking motivation (Gomez et al., 2010). Ghanbari Arbastan et al. (2016) and Torkfar et al. (2017) also, Came to the conclusion that that the most important obstacle in participation of female in sport is economic obstacle.

In sum, the strategy plan of women's championship sports of Guilan has been designed according to the selected model and all the mentioned subjects in that have been processed accordingly. Also, the researchers tried to keep the necessary harmony, coherence and cohesion among the strategy notions as far as possible. Furthermore, it should be noted that considering the score of internal and external factors matrixes, the defensive strategy should be used in women's championship sports of Guilan. 


\section{REFERENCES}

Ansoff, H.I. (1994), comment on henry mintzberg's rethinking strategic planning: long range planning, 27(3), pp. 31-32,

David, F.R. (1989), How companies define their mission: Long range planning, 22(1), p. 90-97.

Dixon, M.A., Warner, M.S. and Bruening, J. (2008), More than just letting them play: Parental influence on women's lifetime sport involvement. Sociology of Sport Journal, 25(4), pp. 538-559.

Fry, F.L. and stoner, C.R. (1995), Strategic Planning for the new and Small Business. Startup publishing company: INC.

Ghahramani, J., Moharram zade, M. and Saeeidi, S. (2013), Barriers affecting the participation rate of women teachers in schools in three school sports activities Marand. Applied research in sport Management, 2(2), PP. 57-66.

Ghanbari Arbastan1, M., Zarei, A. and Tojjari, F. (2014), design and development of strategic plan of women's sport for all. Indian Journal of Fundamental and Applied Life Sciences, 4(3), PP. 1004-1009.

Gómez-López, M., Gallegos, A.G. and Extremera A.B. (2010), Perceived barriers by university students in the practice of physical activities. Journal of Sports Science and Medicine, 9(3), pp. 374-381.

Gould, D., Guinan, D., Greenleaf, C., Medbery, R. and Peterson, K. (1999), Factors affecting Olympic performance: Perceptions of athletes and coaches from more and less successful teams. The sport psychologist, 13(4), pp. 371-394.

Hill, C.W.L.and Jones, G.R. (1992), Strategic Management: An Integrated Approach: Houghton Mifflin Company.

Hunger, J.D. and Wheelen, T.L. (2012), Essentials of strategic management: Prentice Hall New Jersey.

Jahedi, H., Torkfar, A. (2015), Effective Obstacles on Women Participation in Student`s Sport activities in Qeshm Azad University. Journal of changde teachers university-natural science edition, 4(2), PP. 8996.

Khabiri, M. and Memari, J. (2011), SWOT analysis of the Iranian Taekwondo. Journal of Sport Management Review, 4(15), pp. 13-30.

Meenaghan, T.(2001), Understanding sponsorship effects. Psychology and Marketing, 18(2), pp. 95-122.

Mester, I., Badulescu, A., Bac, O. and Bac, D.(2008), Qualitative and quantitative analysis of the sport tourism from the perspective of romanian young adults: MPRA.

Monazami, M., Alam, S.H. and Boushehri, N. (2010), The Identification of Effective Factors in the Development of Women's Physical Education and Sport in Islamic Republic of Iran. Journal of Sport Management, 10(3), pp. 151-168.

Motameni, A., Hemati, A. and Moradi, H. (2014), Identifying and prioritizing the barriers for women's sports activities. Sport Management Studies, 6(24), pp. 111-130.

Olsen, J.B. and Eadie, D.C. (1982), The game plan: Governance with foresight: Natl Governors Assn.

Pearce, J.A. and Robinson, R.B. (1997), Strategic management: Formulation, implementation, and control: Irwin Chicago, Illinois.

Pitts, B. and Pedersen, P.M. (2005), Examining the body of knowledge in sport management: A content analysis of the Journal of Sport Management. Sport Management and Related Topics Journal, 2(1), pp. 33-52.

Rasekh, N., Sajjadi, N., Hamidi, M. and Khabiri, M.(2012), The Design of a Strategic Plan for Iran Female Championships. Journal of Sport Management, 7(3), pp. 309-334. 
Journal of Global Strategic Management | V. 11 | N. 2 | 2017-December | isma.info | 063-076 | DOI: 10.20460/JGSM.2018.253

Torkfar, A., Education, S. B., Shirazinejad, R., Jahromi, N.N. and Branch, J. (2017), Women's Participation in Sports Predictions based on Social, Cultural, Personal, Family Factors, and Facilities in the City Pasargad. Jurnal Fikrah, 2(8), pp. 181-195. 